\title{
Promoting ergonomics in Algeria: Activities of "the research and training laboratory" in the University of Oran
}

\author{
Bouhafs Mebarki ${ }^{\mathrm{a}}$ Tebboune Cheikh El-Bachir ${ }^{\mathrm{b}}$ \\ ${ }^{a}$ Faculté des sciences sociales, Université d'Oran, Algeria. \\ E-mail:b_mebarki@yahoo.fr \\ ${ }^{\mathrm{b}}$ Faculté $\bar{d}$ médecine, Université d'Oran, Algeria. \\ E-mail:btebboune@yahoo.fr
}

\begin{abstract}
The growing need in Algeria to develop ergonomics knowledge and practice in industry was behind the initiative to develop a training and research project within the ergonomics laboratory at Oran University. Since 2005 the laboratory team is running an academic option master in work design and ergonomics. The evaluation of the academic master in 2010 revealed the acute need of the local industry for professional competences in ergonomic and work psychology. A professional training master program in "ergonomics \& work psychology" was then developed in partnership with local industry, five European Universities and six Universities from three Maghreb countries. Research projects were initiated around the two training programs, in conjunction with a number of ergonomics dissemination and promotion activities.

Preliminary results of the project are presented and discussed in relation to the local context, and in the light of similar cases in Industrially Developing Countries.
\end{abstract}

Keywords: promoting and disseminating ergonomics; knowledge and practice; research and training; ergonomic and work psychology; partnership.

\section{Introduction}

Literature on the promotion and dissemination of ergonomics knowledge and practice in many parts of the developing world are well documented $[1,3,5,6$, $10,12]$. While in the Algerian case, a shortage of published materiel on ergonomic activities (research, training, expertise) is well noticed.

For the sustainability of ergonomic programs Stewart et al. (2005) [14] argued that "Industrially developing countries should seek to establish a permanent ergonomic infrastructure capable of providing training, dissemination information (...) this approach would be best achieved through a multicountry and multi-organizational approach".

Although the application of ergonomics in Industrially Developing Countries (IDCs) suffers from drawbacks like: the limited infrastructure to support ergonomics activity and interventions [11], and the ignorance of the comprehensive nature of ergonomics and the benefits it can deliver [10].
The project created a research and training laboratory as a main cell in which the different tasks were performed.

Inspired of experiences of ergonomists in (IDC), a team of ergonomists at Oran University, initiated in 2005, an ergonomics project to promote ergonomics through training and research activities. For the project to be materialized, (i) an ergonomics laboratory was set up, to play a central role as the main cell in which the different tasks were performed, and (ii) a training program at master level was launched.

The purpose of this paper is to describe the experience and achievements of the project throughout two complementary stages of the process of promoting ergonomics knowledge and practice from 2005 to 2011.

\section{Methods}

The project was elaborated to achieve the following goals: 
- Create a research and training laboratory to gather competencies in ergonomics around topics of interests.

- Train ergonomists at master and PhD levels.

- Carry out research projects in partnership with different industries, covering a variety of issues to improve working conditions

Since 2005, the project has gone through two main stages:

\subsection{The first stage of the project:}

Training ergonomists at master and PhD levels: A master degree course (academic option) in "work design \& ergonomics" was launched and accredited by the Algerian ministry for higher education for the academic year 2005/2006.

\subsection{The second stage of the project:}

In January 2010, the training team engaged an evaluation and expertise operation, in order to develop a master course in "ergonomics and work psychology". In partnership with five European Universities, six Universities from three Maghreb countries, and local industrial partners from small and medium industry and petroleum sector, the expertise report submitted in June 2010 (MPTUM, 2010) [9], revealed the following Conclusions:

- When ergonomic intervention is a major goal of the training program, the academic option of the master offers limited skills to students. Hence, a professional/practitioner's option seems to be more suitable.

- The lack of awareness and recognition of the potential benefits of ergonomics among stakeholders (enterprises, government administrations, etc.) seems to be a major obstacle facing the promotion and dissemination process of ergonomics.

- Ergonomic intervention is acutely needed in Algerian industrial settings, both at micro and macro ergonomics levels, a situation which should be taken into account when elaborating training programs.

- To be adequately executed, the ergonomics promotion plan needs to acquire the necessary training and research facilities.

To overcome these drawbacks, the project team took the following steps:

- Promote a professional/practitioner option of the master degree in partnership with user sectors (industry, government services, employment agencies, heath authorities).
- Seek the international collaboration and partnership in the design and elaboration of the different aspects of the master (syllabus elaboration, curricula design, on site training, accreditation, quality assurance, etc.).

\section{Results}

\subsection{Outcome of the first stage of the project:}

3.1.1. Education and training: Fourteen (14) students were accredited the master degree (academic option) in "work design \& ergonomics", and seven (7) $\mathrm{PhD}$. degrees in the same option are in different preparation stages. For the academic year 2011/2012, fifteen (15) students are registered in their first year master (M1).

3.1.2. Research activities: A number of research projects were carried out in partnership with different industries, covering a variety of issues to improve working conditions like: work organization \& workstation design, physical work environment and school ergonomics issues.

Research projects were conducted in line with the national program of scientific research which sets out the national priorities of scientific research in Algeria. These projects covered the following issues:

\section{- Environmental work conditions:}

a. Evaluation of noise levels and its impact on hearing deterioration among the working population in a variety of work settings, indoor (foundry works) and outdoor (construction and building sites, quarry mines and stone grinding stations)

b. Light and thermal conditions in VDU work stations (sight and performance)

c. Extreme thermal conditions in hot and dusty Saharan environment

- Musculoskeletal Disorders (MSD) in different work situations:

a. Ergonomics evaluation of the phenomenon: extent, causes and the population at risk.

b. MSD in handling tasks and VDU work tasks.

c. MSD among school children.

d. MSD and varicose in standing postures among hospital nursing personnel.

- Stress and strain issues among shift workers, nursing personnel and teachers.

- Educational ergonomics 
a. Evaluation of school furniture in primary, middle and secondary schools.

b. Anthropometry of school children from the age of 6 to 16 .

- Ergonomics of risks:

a. Risk perception and risk evaluation in the light of psychological social and cultural factors.

b. Elaboration of psychometric tools for measurement of risk situations.

\subsubsection{Organization of the ergonomics laboratory:} gathering competencies in ergonomics around topics of interests was one of the main missions of the laboratory. For the multidisciplinary and applied nature of ergonomics, competencies in ergonomics are scattered geographically through out different universities and faculties (engineering, medical and social sciences), and in different work settings (production and service organizations). The ergonomics laboratory at Oran University played a key role, as a focal meeting space, to gather individual initiatives and ideas, to elaborate the necessary action plans for the dissemination of ergonomics principles and practices. The laboratory counts fifteen (15) members organized in four (4) research teams covering the following areas of interest:

- Ergonomics and occupational risks.

- Health and Safety at work.

- Ergonomics for Children and Educational Environment.

- Ergonomic design of workspaces.

The laboratory offers facilities of research equipment, library and documentation materiel, beside space facilities to organize conferences, seminars, meetings and open days of ergonomics, for industry, students and the large public.

\subsection{Outcome of the second stage of the project:}

Beside the Master (academic option) in "work design \& ergonomics", the team has launched a master degree (professional/practitioner option) in "ergonomics \& work psychology", which is in its first year (2011/2012) with a total of 25 students. This master is run under the TEMPUS program (European Tempus Project: 159287-2009), financed by the European Commission of Education, accredited in line with the Bologna process of higher education reforms [4]. The master is a step towards the accreditation standards evoked in Smith (2009) [13].

To put the recommendations of the evaluation report [9] into practice the following actions were taken before commencing students' training:

- The training team elaborated the training curricula and the different syllabus of the master, with the partnership and the collaboration of local industry and public administration as stakeholders, and with the expertise and close implication of the European experts (professors of ergonomics and work psychology)

- As the training site (enterprise) is a precondition for any professional master in ergonomics and organizational psychology, formal consents of the different partner enterprises were signed before the official enrollment of the students.

- A "train the trainer's" wok shops process was engaged by professors of the European partner universities in favor of the local teachers and instructors to allow them to be up to date with different aspects of the master management.

- Acquire the necessary equipment and material to execute the training program.

Both master degrees are run in partnership with local industrial and service sectors.

\section{Discussion}

The lessons learned from the first stage of the project were of great importance to the team, in addition to the points outlined in the results; other lessons learned include the following:

- Professional training of ergonomists is a precondition to the success of any ergonomics intervention. This conclusion was materialized through the master of ergonomics and work psychology.

- The promotion and dissemination of ergonomics knowledge and practice can not be achieved without the effective commitment of the different users and stakeholders. Much of the time has being spent during the second phase of the project in informing the different stakeholders, particularly, industrial partners of the outcomes of ergonomics and "the importance of economics of ergonomics which should be an integral part of any course" as has been outlined by Stewart et al. (2005) [14] in order to motivate enterprises to fully participate in the training program. 
- To successfully be carried out, ergonomics promotion and dissemination projects in IDCs should not merely focus on large-scale industries. Small and medium-sized enterprises (SMEs) are best fit, to easily accommodate ergonomics interventions [2, $7,8]$. Beside their capacities to employ most of the working population and generate the largest part of incomes in IDCs.

- The European partnership project "Tempus 159287-2009" was an added value to local efforts, particularly in aspects of expertise and know how, like: curriculum content structure, quality insurance and the new trends of the discipline, which constituted the main themes of the different work shops and training sessions of the local trainers.

\section{5- Conclusions}

While positive results of the project are well established, the process of promoting and disseminating ergonomics knowledge and practice is an ongoing one.

The assessment of what has been realized under the present project revealed many encouraging results in aspects of ergonomics education and training programs, research activities and partnerships with industry and universities from Algeria, Europe and Maghreb countries. The sustainability of the project and its evolution is guaranteed by the commitment of the different partners and stakeholders.

\section{References}

[1] Adaramola, S.S., Ergonomics Practice in Nigeria Today. Proceedings of 17 th World Congress on Ergonomics, IEA, Beijing, 2009.

[2] Ahasan Rabiul., Occupational health, safety and ergonomic issues in small and medium-sized enterprises in a developing country. Academic Dissertation University of Oulu, Finland, 2002.

http://herkules.oulu.fi/isbn9514268121/index.html?lang=en
[3] Caple, D., The IEA contribution to the transition of ergonomics from research to practice. Applied Ergonomics, vol. 41, issue 6, October 2010, pages 731-737.

[4] European Tempus Project: 159287-2009; Education, Audiovisual \& Culture Executive Agency. http://eacea.ec.europa.eu/tempus.

[5] Helali F., Using Ergonomics Checkpoints to Support a Participatory ergonomics intervention in an industrially developing country (IDC) - A case study. International Journal of Occupational Safety and Ergonomics (JOSE), Vol. 15, No. 3, 325-337, 2009

[6] Kogi K. A., Developing Ergonomics Societies in Industrially Developing Countries, , International Ergonomics Association,2002, www.iea.cc

[7] Kogi K A., Improving working conditions in small enterprises in developing Asia. Geneva: International Labour Office, 158p. 1985.

[8] Kogi K A., Phoon W. O \& Thurman J.E., Low-cost ways of improving working conditions: 100 examples from Asia. Geneva: International Labour Office, 179p. 1989.

[9] MPTUM (2009) Projet Tempus 159287-2009 «Développement et accompagnement d'un Master en Psychologie du Travail dans des universités du Maghreb. Compte rendu de la visite d'expertise pédagogique des membres du consortium TEMPUS 159287-2009 (MPTUM) Oran, du 16 au 19 juin 2010. Available from:

http://www.mptum.net/uploads/piece_jointe_univ_oran/expert ise pedagogique Oran version finale definitive.pdf

[10] O'Neill D. H., The promotion of ergonomics in industrially developing countries. International Journal of Industrial Ergonomics. 2005; 35:163-8.

[11] O'Neill D. H., Ergonomics in industrially developing countries: does its application differ from that in industrially advanced countries? Applied Ergonomics, Volume 31, Issue 6, December 2000, Pages 631-640.

[12] Shaliza Azreen Mustafa, Shahrul Kamaruddin, Zalinda Othman and Mohzani Mokhtar, Ergonomics Awareness and Identifying Frequently Used Ergonomics Programs in Manufacturing Industries Using Quality Function Deployment. American Journal of Scientific Research, Issue 3(2009), pp.51-66. http://www.eurojournals.com/ajsr.htm

[13] Smith, T.J., The future of Ergonomics in Education - Panel Session, $17^{\text {th }}$ World Congress on Ergonomics. IEA 2009 , Beijing, China. 2009.

[14] Stewart, K., B. Silverstein, M. Kiefer, P. Johnson, D. Zalk., Establishing Ergonomics in Industrially Developing Countries. International Occupational Hygiene Association 6th Triennial Conference Pilanesberg, South Africa September 19, 2005 through September 23, 2005. 